\title{
Purification and Characterization of Streptomycin 6-kinase, an Enzyme Implicated in Self-protection of a Streptomycin-producing Micro-organism
}

\author{
By MASANORI SUGIYAMA, * MAKOTO SAKAMOTO, HIROSHI \\ MOCHIZUKI, OSAMU NIMI AND RYOSAKU NOMI \\ Department of Fermentation Technology, Faculty of Engineering, Hiroshima University, \\ Saijo-cho, Higashi-Hiroshima 724, Japan
}

(Received 12 October 1982; revised 16 December 1982)

\begin{abstract}
Streptomycin 6-kinase of the streptomycin-producing strain Streptomyces griseus HUT 6037 was purified by fractionation with $\left(\mathrm{NH}_{4}\right)_{2} \mathrm{SO}_{4}$ and chromatography on DEAE-Sephadex A-25, hydroxyapatite and Sephadex G-100. After PAGE of the final fraction, a protein band corresponding to streptomycin 6-kinase was detected, together with a less intense band having no enzyme activity. Molecular weights determined by SDS-PAGE and by Sephadex G-100 chromatography were about 36000 and 38000 , respectively, suggesting that the enzyme was a monomer. The isoelectric point of the enzyme was pH 6.6. Among the nucleoside 5'triphosphates tested, ATP was the preferred phosphoryl donor. The $K_{\mathrm{m}}$ values for streptomycin and ATP were $3.5 \mathrm{~mm}$ and $0.4 \mathrm{mM}$, respectively. The enzyme activity was strongly inhibited by EDTA and $\mathrm{AgNO}_{3}$. It was shown by using an in vitro protein-synthesizing system that purified streptomycin 6-kinase could protect polyphenylalanine synthesis of the streptomycinsusceptible $S$. griseus strain KSN from inhibition by streptomycin.
\end{abstract}

\section{INTRODUCTION}

Walker \& Walker (1967) found an enzyme which catalysed phosphorylation of streptidine with ATP in extracts of post-exponential phase mycelia of streptomycin (SM)-producing microorganisms. Since this enzyme phosphorylated SM and dihydrostreptomycin in preference to streptidine (Miller \& Walker, 1969), it was suggested that the enzyme might be more accurately designated as streptomycin kinase. Nimi et al. $(1971 a, b)$ also found a kinase which phosphorylated the C6 hydroxyl group of the streptidine moiety of SM in the presence of ATP and $\mathrm{Mg}^{2+}$, and it was very probably the same enzyme as that described by Miller $\&$ Walker (1969). This streptomycin 6-kinase (SM 6-kinase; EC 2.7.1.72, ATP : streptomycin 6-phosphotransferase) has been supposed to play a role in the phosphorylation of some intermediate on the biosynthetic pathway to SM, or to phosphorylate streptomycin in the cell as a means of selfprotection from the lethal effect of the drug (Nimi et al., 1971a,b). We demonstrated recently that while the ribosomes of SM-producing Streptomyces griseus bound SM (Sugiyama et al., $1980,1981 a, b$ ), the bound SM was released by phosphorylation with SM 6-kinase (Sugiyama et $a l ., 1981 b$ ). SM 6-phosphate did not inhibit protein synthesis in extracts of the SM-producer (Sugiyama $e t$ al., 1982). From these results, it was concluded that although the ribosomes of the SM-producer were susceptible to the antibiotic product, protein synthesis could be protected from the action of the drug by phosphorylation of the latter with SM 6-kinase. Nimi et al. $(1971 b)$ partially purified SM 6-kinase. The present study involved further purification of the enzyme and the determination of some of its properties.

Abbreriations: PMSF, phenylmethane sulphonyl fluoride; SM, streptomycin; SM 6-kinase, streptomycin 6kinase. 


\section{METHODS}

Micro-organisms. The SM-producing $S$. griseus HUT 6037 strain and the non-producing $S$. griseus KSN strain (Sugiyama et al., 1981 $a, b, 1982$ ) were used. The latter strain, derived from HUT 6037, did not produce SM 6kinase and was susceptible to SM.

Preparation of an acetone powder. Streptomyces griseus HUT 6037 was grown in $1 \%(\mathrm{w} / \mathrm{v})$ glucose/meat extract/peptone (GMP) medium (Nimi et al., 1976) at $28^{\circ} \mathrm{C}$ in a 301 jar fermenter and the mycelium was harvested at the late exponential phase of growth. The mycelium was washed twice with $0.5 \%(\mathrm{w} / \mathrm{v}) \mathrm{NaCl}$ at $0{ }^{\circ} \mathrm{C}$, then thoroughly washed with acetone and dried in vacuo.

Determination of protein. The protein in eluates from column chromatography was monitored by following the absorbance at $280 \mathrm{~nm}$. The protein in enzyme solutions was determined by the Lowry method using BSA as a standard.

Assay of SM 6-kinase activity. SM 6-kinase activity was determined by two methods. Method A involved determination of SM 6-[32 P]phosphate produced by the enzyme from SM and adenosine $5^{\prime}-\left[\gamma^{-32} \mathrm{P}\right]$ triphosphate (Sugiyama et al., 1981 b). Method B involved determination by bioassay of the decreased amount of active SM after phosphorylation of SM by the enzyme (Nimi et al., $1971 \mathrm{~b}$ ). Since the former method was inadequate when salt concentration in the enzyme solution was high, the latter method was employed to determine enzyme activities of eluates from columns of hydroxyapatite and DEAE-Sephadex A-25, as well as the specificity of phosphoryl donor for SM and the $K_{\mathrm{m}}$ value for ATP.

Purification of the enzyme. All procedures were carried out at 0 to $6^{\circ} \mathrm{C}$ and, when necessary, enzyme solutions were stored at $-20^{\circ} \mathrm{C}$.

(a) Preparation of extract. Approximately $48 \mathrm{~g}$ of the acetone powder of $S$. griseus HUT 6037 was suspended in $950 \mathrm{ml}$ TMDP buffer [50 mM-Tris/ $\mathrm{HCl}, \mathrm{pH} 8 \cdot 0,10 \mathrm{mM}-\mathrm{MgSO}_{4} .7 \mathrm{H}_{2} \mathrm{O}, 0.5 \mathrm{mM}$-dithiothreitol and $0.4 \mathrm{mM}$-phenylmethane sulphonyl fluoride and kept in an ice-bath for $1 \mathrm{~h}$ with gentle shaking. The supernatant fluid was obtained by centrifugation at $12000 \mathrm{~g}$ for $40 \mathrm{~min}$.

(b) $\left(\mathrm{NH}_{4}\right)_{2} \mathrm{SO}_{4}$ fractionation. Solid $\left(\mathrm{NH}_{4}\right)_{2} \mathrm{SO}_{4}$ was added to the fluid with stirring to give $45 \%$ saturation. After centrifuging at $12000 \mathrm{~g}$ for $40 \mathrm{~min}$, additional $\left(\mathrm{NH}_{4}\right)_{2} \mathrm{SO}_{4}$ was added to the supernatant to give $75 \%$ saturation. The precipitate was collected by centrifugation and dissolved in $182 \mathrm{ml}$ TMDP buffer. The solution was dialysed against 91 of the same buffer for $6 \mathrm{~h}$.

(c) DEAE-Sephadex A-25 chromatography $I$. The dialysed solution was applied to a column $(2 \times 50 \mathrm{~cm})$ of DEAE-Sephadex A-25 equilibrated with TMDP buffer. The column was washed with $200 \mathrm{ml}$ of the same buffer and then with $300 \mathrm{ml}$ TMDP buffer containing $0 \cdot 2 \mathrm{M}-\mathrm{NaCl}$. The enzyme was eluted with TMDP buffer containing $0 \cdot 3 \mathrm{M}-\mathrm{NaCl}$.

(d) Hydroxyapatite chromatography. The active fractions of SM 6-kinase collected from step (c) were loaded on to a column $(1.6 \times 22 \mathrm{~cm})$ of hydroxyapatite (Seikagaku-kogyo Co.) equilibrated with TMDP buffer. The column was washed with $100 \mathrm{ml}$ of the same buffer and then with $80 \mathrm{ml}$ of buffer containing $2 \%(\mathrm{w} / \mathrm{v})\left(\mathrm{NH}_{4}\right)_{2} \mathrm{SO}_{4}$. Elution was carried out with TMDP buffer containing 2 to $7 \%\left(\mathrm{NH}_{4}\right)_{2} \mathrm{SO}_{4}$ (inear gradient of concentration). The active fractions were saturated with solid $\left(\mathrm{NH}_{4}\right)_{2} \mathrm{SO}_{4}$ and kept in an ice-bath overnight. The resulting precipitate was collected by centrifugation at $27000 \mathrm{~g}$ for $20 \mathrm{~min}$ and dissolved in about $2 \mathrm{ml}$ TMDP buffer.

(e) Sephadex G-100 chromatography. The enzyme solution obtained at step (d) was loaded on to a column of Sephadex G-100 $(2 \times 115 \mathrm{~cm})$, previously equilibrated with TMDP buffer. Elution was with TMDP buffer.

( $f$ ) DEAE-Sephadex A-25 chromatography II. The enzyme fraction at the above step was applied to a column of DEAE-Sephadex A-25 $(0.7 \times 15 \mathrm{~cm})$ previously equilibrated with TMD buffer which had been prepared by omitting PMSF from the TMDP buffer. The column was washed with $50 \mathrm{ml}$ TMD buffer and then with $50 \mathrm{ml}$ of the buffer containing $0 \cdot 15 \mathrm{M}-\mathrm{NaCl}$, before being eluted with TMD buffer containing $0 \cdot 15$ to $0 \cdot 4 \mathrm{M}-\mathrm{NaCl}$ (linear gradient of concentration). The enzyme was recovered in the fractions containing about $0 \cdot 2 \mathrm{M}-\mathrm{NaCl}$. The fractions giving high enzyme activity were pooled, dialysed against TMD buffer and then used for determination of some properties of the enzyme.

In these purification steps, addition of PMSF to the buffer was necessary to prevent inactivation of SM 6-kinase by proteolytic activity. Without use of the protease inhibitor, $80 \%$ of SM 6-kinase activity in the extract of the acetone powder was lost within $2 \mathrm{~d}$ at $5{ }^{\circ} \mathrm{C}$. The purified enzyme was stable at $-20^{\circ} \mathrm{C}$ for a few months.

Disc gel electrophoresis. Enzyme purity was determined by disc gel electrophoresis at $\mathrm{pH} 8.0$ using a $7 \%(\mathrm{w} / \mathrm{v})$ polyacrylamide gel $(0.5 \times 0.5 \mathrm{~cm}$ stacking gel and $0.5 \times 5 \mathrm{~cm}$ separating gel) (Williams \& Reisfeld, 1964). Coomassie brilliant blue R250 $[0 \cdot 2 \%(\mathrm{w} / \mathrm{v})$ in $50 \%(\mathrm{v} / \mathrm{v})$ methanol $/ 7.5 \%(\mathrm{v} / \mathrm{v})$ acetic acid solution] was used for staining protein bands and $20 \%$ methanol $/ 7.5 \%$ acetic acid solution was used for de-staining.

Isoelectric focusing. The isoelectric pH of enzyme was determined by using Servalyt-Precotes no. 42967 (SERVA Feinbiochemica, Heidelberg, F.R.G.) containing carrier polyampholytes, $\mathrm{pH} 3$ to 10 . Cathode and anode solutions were $1 \mathrm{M}-\mathrm{NaOH}$ and $1 \mathrm{M}-\mathrm{H}_{3} \mathrm{PO}_{4}$, respectively. Isoelectric focusing was performed for $3 \mathrm{~h}$ at $1000 \mathrm{~V}$. The protein band was stained with Coomassie brilliant blue after treatment of the Precotes with a fixing solution consisting of $150 \mathrm{ml}$ methanol, $350 \mathrm{ml}$ deionized water, $57.6 \mathrm{~g}$ TCA and $17.25 \mathrm{~g}$ sulphosalicylic acid. De-staining was done as described above. 
Molecular weight determination. Molecular weight was determined by SDS-PAGE according to the method of Laemmli (1970) and by Sephadex G-100 column chromatography. Marker proteins used in the electrophoresis were phosphorylase b (94000), BSA (67000), ovalbumin (43000), carbonic anhydrase (30000), soybean trypsin inhibitor (20100), and $\alpha$-lactalbumin (14400). Marker proteins loaded on to a Sephadex G-100 column $(2 \times 115 \mathrm{~cm})$ together with the enzyme solution were BSA, egg-white albumin (45000), chymotrypsinogen A (25000) and cytochrome $c(12500)$. The column was eluted with TMD buffer at the rate of $11.4 \mathrm{ml} \mathrm{h}^{-1}$ and $3.8 \mathrm{ml}$ fractions were collected. A portion $(40 \mu \mathrm{l})$ of each fraction was assayed for SM 6-kinase activity by method A. Positions of marker proteins were established by their absorbance at $280 \mathrm{~nm}$.

Preparation of ribosomes and $S$-150 fraction. Cells of $S$. griseus $\mathrm{KSN}$, harvested at the late exponential phase of growth, were washed twice with buffer I (10 mM-Tris/HCl, pH 7.65, $10 \mathrm{~mm}$-magnesium acetate, $1 \mathrm{M}-\mathrm{KCl}, 6 \mathrm{mM}-2$ mercaptoethanol and $5 \mathrm{mM}$-EDTA dipotassium magnesium salt), and then twice with buffer II (10 mM-Tris/ $\mathrm{HCl}$, pH 7.65, $10 \mathrm{~mm}$-magnesium acetate, $30 \mathrm{~mm}-\mathrm{NH}_{4} \mathrm{Cl}, 6 \mathrm{~mm}$-2-mercaptoethanol, $5 \mathrm{~mm}$-EDTA dipotassium magnesium salt, $0.2 \mathrm{~mm}$-diisopropyl fluorophosphate and $3.45 \mathrm{~mm}$-PMSF). The washed cell pellet was ground with quartz sand and extracted with buffer II containing $2 \mu \mathrm{g}$ DNAase $\mathrm{I} \mathrm{ml}^{-1}$. The extract was centrifuged at $30000 \mathrm{~g}$ for $30 \mathrm{~min}$. From the supernatant, the ribosomes were sedimented by centrifugation at $150000 \mathrm{~g}$ for $3 \mathrm{~h}$, then washed with buffer III $\left(20 \mathrm{~mm}\right.$-Tris/ $\mathrm{HCl}, \mathrm{pH} 7 \cdot 65,1 \mathrm{M}-\mathrm{NH}_{4} \mathrm{Cl}, 10 \mathrm{mM}$-magnesium acetate, $6 \mathrm{mM}-2$-mercaptoethanol, $1.1 \mathrm{M}$-sucrose, $5 \mathrm{~mm}$-EDTA dipotassium magnesium salt, $0.2 \mathrm{~mm}$-diisopropyl fluorophosphate and 3.45 mM-PMSF) by the method of Fahnestock et al. (1974), and then dialysed against buffer IV (10 mM-Tris/ $\mathrm{HCl}$, $\mathrm{pH} 7 \cdot 65,10 \mathrm{~mm}$-magnesium acetate, $30 \mathrm{mM}-\mathrm{NH}_{4} \mathrm{Cl}$ and $6 \mathrm{~mm}$-2-mercaptoethanol). The upper one-third portion of the supernatant obtained by centrifugation at $150000 \mathrm{~g}$ was dialysed against buffer IV and used as the S-150 fraction.

Assay of in vitro protein synthesis. The in vitro protein synthesis was performed by modifying the method of Kobayashi et al. (1977). The reaction mixture $(125 \mu \mathrm{l})$ contained $60 \mathrm{mM}$-Tris/ $\mathrm{HCl}, \mathrm{pH} 7 \cdot 8,8 \mathrm{~mm}-\mathrm{magnesium}$ acetate, $80 \mathrm{~mm}-\mathrm{NH}_{4} \mathrm{Cl}, 6 \mathrm{mM}$-2-mercaptoethanol, 0.4 mM-spermidine, $0.9 \mathrm{~mm}$-ATP (disodium salt), $0.2 \mathrm{mM}-\mathrm{GTP}$ (disodium salt), $4 \mathrm{~mm}$-phosphoenolpyruvate, $2 \mu \mathrm{g}$ pyruvate kinase, $0.05 \mu \mathrm{Ci} \mathrm{L}-\left[\mathrm{U}-{ }^{14} \mathrm{C}\right]$ phenylalanine $(100 \mu \mathrm{Ci}$ $\left.\mu \mathrm{mol}^{-1} ; 3.7 \mathrm{MBq} \mu \mathrm{mol}^{-1}\right), 4 \mu \mathrm{M}$ each of 19 amino acids except phenylalanine, $25 \mu \mathrm{g}$ tRNA from Escherichia coli MRE 600 (Boehringer), $25 \mu \mathrm{g}$ polyuridylate, $60 \mu \mathrm{g}$ ribosomes and $240 \mu \mathrm{g} \mathrm{S}-150$ fraction as protein. After incubating at $28{ }^{\circ} \mathrm{C}$ for $30 \mathrm{~min}, 10 \%(\mathrm{w} / \mathrm{v})$ cold TCA $(1 \mathrm{ml})$ was added prior to heating at $90{ }^{\circ} \mathrm{C}$ for $15 \mathrm{~min}$. The precipitate was collected on a glass fibre disc (Whatman GF/F, $25 \mathrm{~mm}$ in diameter) and washed twice with $5 \mathrm{ml}$ $5 \%$ TCA. The radioactivity on the filter was estimated with a liquid-scintillation spectrometer using BBOT/ toluene scintillation mixture.

\section{RESULTS AND DISCUSSION}

Purity of the enzyme. The results of a typical purification are summarized in Table 1. PAGE of the enzyme from step $(f)$ (see Methods) revealed a main protein band which corresponded to the single peak of SM 6-kinase activity measured in gel slices, together with a less intense protein band which had no SM 6-kinase activity.

Substrate specificity and kinetics of the enzyme. Pure SM 6-kinase was obtained by slicing the electrophoresis gels and was compared with the enzyme solution at step $(f)$ of the purification with respect to the $K_{\mathrm{m}}$ value for SM. Since the $K_{\mathrm{m}}$ values of these two preparations were $4 \mathrm{mM}$ and $3.5 \mathrm{mM}$, respectively, activity of SM 6-kinase was apparently hardly affected by the contaminating protein. Thereafter, the enzyme fraction from step $(f)$ was employed for characterization. The highly purified enzyme catalysed the phosphorylation of SM, dihydrostreptomycin and streptidine. The phosphorylating affinity $\left(V_{\max } / K_{\mathrm{m}}\right)$ of SM 6-kinase for SM was about 20-fold and 4-fold higher than that for streptidine and dihydrostreptomycin, respectively (Table 2 ).

Molecular weight and isoelectric pH of the enzyme. The molecular weight of SM 6-kinase was estimated to be about 36000 by SDS-PAGE, and about 38000 by chromatography on Sephadex $\mathrm{G}-100$. These results suggest that the enzyme is a monomer. The isoelectric pH of SM 6-kinase was found to be $\mathbf{6 \cdot 6}$.

Phosphoryl donor specificity. ATP was the preferred phosphoryl donor to SM $\left(K_{\mathrm{m}}=0.4 \mathrm{mM}\right)$. CTP, UTP and GTP gave hardly any activity.

Metal ion requirement. $\mathrm{Mg}^{2+}(10 \mathrm{mM})$ was required for maximal activity. $\mathrm{Co}^{2+}$ and $\mathrm{Cu}^{2+}$ $(10 \mathrm{mM})$ were rather less stimulatory than $\mathrm{Mg}^{2+} . \mathrm{Mn}^{2+}, \mathrm{Zn}^{2+}$ and $\mathrm{Fe}^{2+}$ all stimulated activity slightly at $10 \mathrm{~mm}$ but $\mathrm{Ca}^{2+}(0 \cdot 1$ to $100 \mathrm{~mm})$ had no significant effect on activity.

Inhibitors of the enzymic activity. The activity was strongly inhibited by $\mathrm{AgNO}_{3}(0 \cdot 1 \mathrm{~mm})$ and EDTA (25 mM). p-Chloromercuribenzoate ( $1 \mathrm{mM}), \mathrm{KCN}, \mathrm{NaN}_{3}$ and monoiodoacetic acid (up 
Table 1. Purification of SM 6-kinase

\begin{tabular}{|c|c|c|c|c|c|}
\hline Purification step & $\begin{array}{c}\text { Volume } \\
(\mathrm{ml})\end{array}$ & $\begin{array}{l}\text { Total } \\
\text { protein } \\
(\mathrm{mg})\end{array}$ & $\begin{array}{c}\text { Specific } \\
\text { activity } \\
\text { of } \\
\text { SM 6-kinase* }\end{array}$ & $\begin{array}{l}\text { Yield } \\
(\%)\end{array}$ & $\begin{array}{l}\text { Purification } \\
\text { (fold) }\end{array}$ \\
\hline $\begin{array}{l}\text { (a) Extract from } \\
\text { acetone powder } \\
\text { (b) }\left(\mathrm{NH}_{4}\right)_{2} \mathrm{SO}_{4}\end{array}$ & 743 & 2191 & 0.49 & - & 1 \\
\hline precipitate & 182 & 1001 & 0.71 & $66 \cdot 1$ & 1.45 \\
\hline (c) DEAE-Sephadex A-25 & 187 & 58 & 11 & $58 \cdot 9$ & $22 \cdot 4$ \\
\hline (d) Hydroxyapatite & 110 & $5 \cdot 2$ & 80 & $39 \cdot 1$ & 163 \\
\hline (e) Sephadex G-100 & $38 \cdot 5$ & 1.92 & 130 & $23 \cdot 1$ & 265 \\
\hline (f) DEAE-Sephadex A-25 & $20 \cdot 0$ & 0.1 & 681 & $6 \cdot 3$ & 1390 \\
\hline
\end{tabular}

* SM 6-kinase activities were determined by method B; specific activities are expressed as $\mu$ mol SM 6-phosphate formed (mg protein) $)^{-1} \mathrm{~h}^{-1}$.

\section{Table 2. Substrate kinetics of SM 6-kinase}

Values were obtained using the enzyme preparation that contained a contaminant protein [step $(f)$ of the purification].

\begin{tabular}{lccc}
\multicolumn{1}{c}{ Substrate } & $\begin{array}{c}\boldsymbol{K}_{\mathrm{m}} \\
(\mathrm{mM})\end{array}$ & $\begin{array}{c}V_{\max } \\
\left(\mu \mathrm{mg} \text { min } \mathrm{min}^{-1}\right.\end{array}$ & $\begin{array}{c}V_{\text {max }} / K_{\mathrm{m}} \\
\text { ratio }\end{array}$ \\
SM & 3.5 & 28.6 & 8.17 \\
Dihydrostreptomycin & 11 & 22.2 & 2.02 \\
Streptidine & 28 & $11 \cdot 1$ & 0.40
\end{tabular}

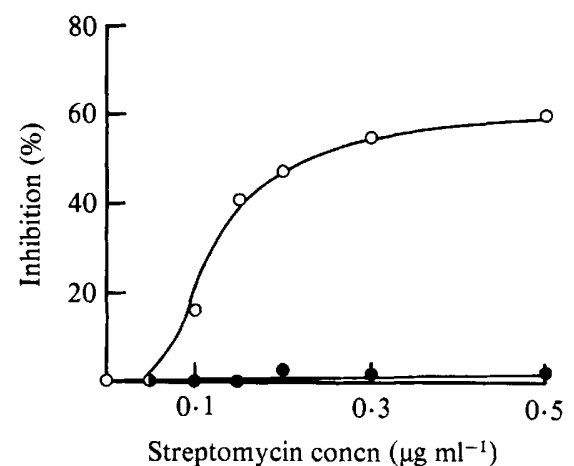

Fig. 1. Protection of polyphenylalanine synthesis from streptomycin inhibition by SM 6-kinase. Percentage inhibition is expressed as the ratio of the lowered level of polyphenylalanine synthesis in the presence of SM to that in the SM-free reaction mixture. A $12.5 \mu$ l portion of the highly purified enzyme $(62.5 \mathrm{ng})$ solution from step $(f)(\mathrm{O})$, or the same volume of TMD buffer $(O)$, was added to the reaction mixture.

to $10 \mathrm{mM}$ ) gave little or no inhibition. Among the analogues of ATP, significant inhibitory effects were observed with adenosine, AMP, ADP and pyrophosphate, but not with adenine (even up to $10 \mathrm{mM}$ ). Inhibition by AMP, ADP and pyrophosphate was non-competitive and the $K_{\mathrm{i}}$ values were 6,5 and $3 \mathrm{~mm}$, respectively. However, inhibition by adenosine was competitive and the $K_{\mathrm{i}}$ value was $0.8 \mathrm{~mm}$.

Protection of protein synthesis by the highly purified SM 6-kinase against inhibition by SM. Streptomyces griseus KSN was susceptible to SM. In vitro polyphenylalanine synthesis by the ribosomes and S-150 fraction from this strain was strongly inhibited by $0 \cdot 1$ to $0.5 \mu \mathrm{g} \mathrm{SM} \mathrm{ml}^{-1}$ 
(Fig. 1). However, the synthesis was protected when the highly purified enzyme was added to the reaction mixture (Fig. 1).

SM 6-kinase has been thought to play an important role in self-protection of the SM producer, because the product, SM 6-phosphate, does not inhibit protein synthesis (Sugiyama et al., 1982) and this observation has now been confirmed by using the highly purified enzyme.

\section{REFERENCES} FAHNESTOCK, S., EDERMANN, V. \& NomuRa, M.
(1974). Reconstitution of 50S ribosomal subunits from Bacillus stearothermophilus. Methods in Enzymology 30, 554-562.

Kobayashi, H., Kobayashi, K. \& Kobayashi, Y. (1977). Isolation and characterization of fusidic acidresistant, sporulation-defective mutants of Bacillus subtilis. Journal of Bacteriology 132, 262-269.

LAEMMLI, U. K. (1970). Cleavage of structural proteins during the assembly of the head of bacteriophage T4. Nature, London 227, 680-685.

Miller, A. L. \& Walker, J. B. (1969). Enzymatic phosphorylation of streptomycin by extracts of streptomycin-producing strains of Streptomyces. Journal of Bacteriology 99, 401-405.

Nimi, O., Ito, G., Sueda, S. \& Nomi, R. (1971 $a$ ). Phosphorylation of streptomycin at $\mathrm{C}_{6}-\mathrm{OH}$ of streptidine moiety by an intracellular enzyme of Streptomyces griseus. Agricultural and Biological Chemistry 35, 848-855.

Nimi, O., Ito, G., Ohata, Y., Funayama, S. \& Nomi, R. (1971b). Streptomycin-phosphorylating enzyme produced by Streptomyces griseus. Agricultural and Biological Chemistry 35, 856-861.

Nimi, O., Kokan, A., Manabe, K., Maehara, K. \& NOMI, R. (1976). Correlation between streptomycin formation and mucopeptide biosynthesis. Journal of Fermentation Technology 54, 587-595.

Sugiyama, M., Kobayashi, H., Nimi, O. \& Nomi, R. (1980). Susceptibility of protein synthesis to streptomycin in streptomycin-producing Streptomyces griseus. FEBS Letters 110, 250-252.

Sugiyama, M., Mochizuki, H., Nimi, O. \& Nomi, R. $(1981 a)$. Roles of streptomycin 6-kinase and ribosomal affinity to streptomycin in self-protection of streptomycin producer. Biotechnology Letters 3, 357362.

Sugiyama, M., Mochizuri, H., Nimi, O. \& Nomi, R. $(1981 b)$. Mechanism of protection of protein synthesis against streptomycin inhibition in a producing strain. Journal of Antibiotics 34, 1183-1188.

Sugiyama, M., Mochizuki, H., Nimi, O. \& Nomi, R. (1982). Assessment of competitive action of streptomycin 6-kinase and streptomycin 6-phosphatase in the in vitro protein synthesis of a streptomycinproducing microorganism. FEBS Letters 139, 331333.

WALKER, J. B. \& WALKER, M. S. (1967). Streptomycin biosynthesis. Enzymatic synthesis of $O$-phosphorylstreptidine from streptidine and adenosine triphosphate. Biochimica et biophysica acta 148, 335-341.

Williams, D. E. \& Reisfeld, R. A. (1964). Disc electrophoresis in polyacrylamide gels: extension to new conditions of $\mathrm{pH}$ and buffer. Annals of the New York Academy of Science 121, 373-381. 